\title{
UNIVERSITYOF
}

FORWARD

THINKING

WESTMINSTER用

WestminsterResearch

http://www.westminster.ac.uk/westminsterresearch

Understanding destination brand love using machine learning

and content analysis method

Seyyed Amiri, N., Pour, Ali Hamedanian, Zaeri, Ehsan and

Nazarian, A.

This is an accepted manuscript of an article published by Taylor \& Francis in Current Issues in Tourism, DOI: 10.1080/13683500.2021.1924634.

The final definitive version is available online:

https://doi.org/10.1080/13683500.2021.1924634

(C) 2021 Taylor \& Francis

The WestminsterResearch online digital archive at the University of Westminster aims to make the research output of the University available to a wider audience. Copyright and Moral Rights remain with the authors and/or copyright owners. 


\section{Understanding Destination Brand Love using Machine Learning and Content 2 Analysis method}

4 Abstract

5 This study aims to apply the concept of brand love in tourist destinations in order to identify

6 the core-elements that could have influential impacts on generating destination brand love. This

7 has been carried out by using a mixed-method of machine learning and content analysis. We

8 have discovered that the topics have been generated for historical landmarks and destinations

9 by analyzing the visitors' on-line reviews are architecture, historical sites, tradition and shrine

10 places, which could be similar to other tourist historical destinations in different part of the

11 world. However, this study has the potential to be a model for other researches related to

12 different destinations with possible different topics emerged. Our study contributes by

13 providing both researchers and managers a novel method to understand what attributes of 14 destination brand love they need to posit more emphasize to attract more visitors based on the 15 destination type.

16 Keywords: Destination Brand Love; Online Reviews; Latent Dirichlet Allocation (LDA); 17 Support Vector Machine (SVM); Content Analysis

19 Brand love is a concept in academic studies which has been described as an emotional 20 attachment generated from customer satisfaction with a particular brand (Huang, 2019). Brand 21 love in recent years has gained popularity and attention among both researchers and 22 practitioners not only because of its positive outcomes on brands, but also due to its impact on brands' performance (Bairrada, 2018). It has been argued that brand love could be positively correlated with electronic word of mouth (e-WOM) (Karjaluoto et al., 2016) and resistance to negative information (Albert et al., 2008; Batra et al., 2012). Furthermore, based on prior studies, it has been proven that brand love is a better and more reliable predictor of loyalty compared to other marketing concepts such as satisfaction, yet it has not been widely investigated in the context of tourism (Aro et al., 2018).

29 In recent years there have been several studies that have investigated the people-place 30 relationship based on place bonding and attachment, whereas there have been few studies that have investigated the concept of brand love or how it is formed (Cheng \& Kuo, 2015). 
Moreover, according to (Aro et al., 2018), there has been a limited number of studies that have focused on the implications, applications, antecedents and consequences of brand love in the context of destination branding. These studies are mainly focused on either the development of the constructs or the investigation of relationships between some concepts such as self-brand integration, passion-driven behaviors and brand love by using traditional data gathering methods including questionnaire surveys.

On the other hand, the emergence of online platforms like TripAdvisor enables tourists to post their experiences in online comments. These online reviews contain valuable information such as concerns, sentiments, and opinions of visitors on products or services that they have received Using online reviews as a source for research data (Guo et al., 2017; Pournarakis et al., 2017) could potentially have major advantages for firms and organizations. Thus, to understand the love of visitors toward a destination brand, and to fill the gap in the existing knowledge of destination brand love, the authors analyzed the data collected through comments posted online to gain insights about how brand love is generated towards the destination brands by using a mixed-method of machine learning and content analysis.

This study responds to the call for additional research on destination brand love in the tourism area (Aro et al., 2018) by analyzing the online reviews of Iran's historical landmarks. This have resulted in generating four different topics; architecture, historical sites, tradition and shrine places, which help to identify the most important and commented core-elements that could directly influence shaping the destination branding. Furthermore, in terms of methodological contribution of this study given the shortcoming and limitation of traditional methods for evaluating visitors' opinion, this study offers a more suitable method that combines the two methods of machine learning and content analysis that will certainly reduce the expense of destination marketing research. The sections of this paper are as follows: Section 2 briefly reviews the relevant literature of brand love and destination brand love; Section 3 presents a methodology utilized in the study; Section 4 employs a case study of the proposed method to clarify its use and finally, in section 5, we discuss the results and present a conclusion.

\section{Literature background}

\subsection{The concept of brand love}

61 Brand love as a construct has been explored in different disciplines, including marketing, by

62 both scholars and practitioners (Ahuvia, 1992; Carroll \& Ahuvia, 2006; Fournier, 1998). Brand 
love is one of the most well-known marketing constructs and has been defined as the degree of emotional and passionate affection that a satisfied consumer has with a particular brand (Carroll \& Ahuvia, 2006) . Love as a deep and long lasting emotion is the main element of the consumer-brand relationship (Maia et al., 2019), hence, numerous studies on brand love have used interpersonal love theory to explain the concept (Sternberg, 1986) or to conceptualize the love of consumers toward brands (Batra et al., 2012). For example, a study by (Carroll \& Ahuvia, 2006) explains that brand love constructs are comparable to sensual love in the interpersonal love theory and, moreover, (Reimann et al., 2012) presents more proof on the similarities between brand love constructs and interpersonal love theory. In fact, the three common constructs of love in the interpersonal theory are (a) intimacy (b) passion and (c) decision/commitment. Intimacy describes connection, closeness, and passion - the initiators of romance, physical attraction, sexual attractiveness, and commitment which are the basis for any decision to be with a person in the short-term or a commitment to extend the relationship for the long-term. The strengths of these components describe the amount of love a person feels.

However several researchers have criticized interpersonal love theory (Batra et al., 2012), arguing that interpersonal love theory is not applicable in the context of brand love, and the connection between two concepts should be made only after its conceptualization based on the more profound insight into the consumer's experience. Their argument is based on good reasons including first, as the most crucial distinction, respondents who participated in their research believed that love toward a brand is less important than interpersonal love; second, interpersonal love is involved with altruistic feelings toward the loved one as a person, however the same feeling does not exist in the case of branding; third, in a healthy relationship among individuals, a mutual feeling exchange including love occurs, but when it comes to brand love, it is not a reciprocated feeling and, finally, self-brand integration, which is about the integration of the brand into customers' identity, is not mentioned in intrapersonal love theory (Aro et al., 2018). Considering this argument, as (Batra et al., 2012) explains, interpersonal love theory cannot truly act as a suitable approach to underpin the concept of brand love.

91 As a result, this study has adopted a proposed model by (Batra et al., 2012) in which the nature 92 and consequences of brand love have been investigated by applying grounded theory. 93 However, due to the tourism context in this study, a modified model consist of first-order and 94 higher-order structural models have been used. Seven core elements have been considered in 95 higher order model; self-brand integration, passion-driven behaviors, positive emotional 
connection, long-term relationship, positive overall attitude valence, attitude certainty and confidence (strength), and anticipated separation distress. Furthermore, high quality/perceived quality of the place has been considered as the antecedent for the destination brand love in this research, and loyalty, WOM and resistance to negative information have been considered as the consequences of the brand love.

Following the view of (Batra et al., 2012), in this study brand love can be also defined as a deep, long-lasting relationship between consumers and brands (Fournier, 1998) that (Rubin, 1973) referred to it as the attitude of consumers, including their feelings, behavior, and thinking about a particular brand. Also, in the work of (Huang, 2019) brand love is considered as the emotional attachment of a satisfied customer toward a brand. Such attachments improve longterm connections between consumers and brands and influence the consumers' loyalty positively. Therefore, customers with higher feelings of satisfaction and love for a brand are probably more committed to follow a repeat-purchase pattern than others (Aro et al., 2018). Hence, it is understandable that brands strive to build a powerful connection with consumers because it has been proved that such a connection increases their financial performance (Malär et al., 2011). On the other hand, brands that generate more love in customers are probably more able to achieve competetive advantages which consequently enhance the organizational performance as compared to other brands that emphasize other marketing concepts more, such as satisfaction (Drennan et al., 2015).

Brand love can also be a useful marketing variable in the tourism context, indeed, the exposure of tourism industry to international competition requires the creation of brand love for tourism destinations that intend to distinguish themselves from other competetiors, probably with a lower marketing cost. In addition, the main advantage of brand love for tourism destinations can be a memoribale experience for the customers so that recollecting them creates pleasing emotions that influence their future travel decisions (Manthiou et al., 2018). Moreover, it worth mentioneing that brand love and the positive emotions generated from a memoriable experience in the visitors could gardualy decline, thus, destinations need to adopt marketing strategies that could create a sense of nostalgia about the destination and provoke the past pleasurable feelings in the visitors, which could encourage them to pay a revisit to the destination (Suzanne et al., 2020). 


\subsection{Conceptualizing destination brand love}

129

130

131

132

133

134

135

136

137

138

139

140

141

142

143

144

145

146

147

148

149

150

151

152

153

154

155

156

157

158

\subsubsection{Antecedent of destination brand love}

Although brand love as a concept has gained popularity among scholars in recent years, destination brand love, which has been derived from brand love, has received limited attention. In a recent study about international students from the Erasmus program of the European Union, Amaro et al. (2020) have adopted destination image as the antecedent of the destination brand love, based on the fact that satisfaction among customers could generally result in brand love. In other words, satisfied customers are more likely to experience brand love, which is aligned with the previous studies (Aro et al., 2018). Although previous researches indicate that satisfaction could be only counted as a requirement and necessity for brand love (Carroll \& Ahuvia, 2006), which means not all the satisfied customers could experience brand love, Aro et al. (2018) argue that satisfaction is an antecedent of destination brand love. Furthermore, they introduced more novel antecedents for destination brand love which could be categorised into three themes; brand experience ( long term relationship, frequent interaction, first visit, positive service interaction, satisfaction, hedonism, attachment to destination, people, feelings), tourist dependent (Anthropomorphism, identification to brand, identification to typical tourists), brand dependent (Place dependence, uniqueness, self-expressiveness of the brand, activity opportunities).

In another study about brand love in destination brand communication, Strandberg et al. (2019) argued that destinations' residents play a substantial role in forming destination brand love due to the reason that their characteristics and values affect the customers' perspective about the destination brand. Indeed, they have adopted self-congruity and self-expressiveness as the antecedents of destination brand love. Based on the results, self-congruity is indirectly related to destination brand love however self-expressiveness has been proved to have a significant positive relationship with destination brand love, which is aligned with past studies in this area (Aro et al., 2018). Moreover, Swanson $(2015,2017)$ have identified basics of a quality tourist destination as the antecedent of destination brand love, which is consist of things to do, weather, people, logistics. However, in our study we have adopted the high quality as the antecedent of destination brand love based on the Batra's brand love model, which represents the tourists' perception about high performance, design and trustworthiness of the brand (Batra et al., 2012). 
160 The tourist destination market has become increasingly competitive because most of the destinations offer the same type of tourism services to visitors (Castañeda-García et al., 2019). In such a dynamic market, creating a positive perception for brands plays a notable role in acquiring new customers. Hence, due to the need for building a positive mental association with brands, branding concepts have been increasingly used in tourism studies. The usage and modification of the branding concepts to fit the tourist industry are categorized as destination branding (Ashworth \& Kavaratzis, 2007; Govers \& Go, 2009). In fact, destination branding is the result of the interaction between the perceived image of places and their inner identity (Hanna \& Rowley, 2011b).

The first and most common aim of destination branding is to initiate positive connections and to clarify the differences of a place with other places (Hanna \& Rowley, 2011). Hence, a significant number of organizations that are in charge of location management endeavour to implement the concept of place branding in practice (Blain et al., 2005). In people-place relationships, two forms of emotional relationships are mostly investigated in the literature (Aro et al., 2018). The first one is place bonding that defines the associated positive emotional connection of a person with a specific place (Cheng \& Kuo, 2015). In Steele's (1981) view, place bonding is a process that a person goes through to bring together multiple experiences with a place. The second and the most salient one is place attachment (Aro et al., 2018), which can be defined as a connection that develops psychologically and emotionally between a person and a place (Prayag \& Ryan, 2012; Tsai, 2012). It is also worth mentioning that tourist places may initiate different positive senses in an individual (e.g., security, trust, confidence, attractiveness), and given the importance of emotions in marketing constructs, place attachment is considered as a marketing strength for tourist places (Tsai, 2012). In fact, it is generated through the involvement of a person with a tourist place (Prayag \& Ryan, 2012), and their emotions such as attractiveness and trust (Hou et al., 2005).

Although place attachment and destination brand love have overlaps, and prior studies have used them interchangeably in the literature (Hammitt et al., 2009), these two concepts seem to

187 have some differences as well. First, and the most crucial difference, is that the destination

188 brand love is a more comprehensive concept than place attachment in terms of describing the relationship between visitors' and places (Prayag \& Ryan, 2012; Tsai, 2012). Second, place 
191 that destination branding is a much more attractive and sophisticated concept as compared to destination attachment, it could be more useful and practical to investigate the relationship between the visitors and places through destination brand love rather than simply assuming

194 place attachment is an appropriate and unique approach in defining the people-place 195 relationships.

196 Moreover, investigating people-place relationships, (Ahuvia, 1992) shows that people can feel 197 love, being defined as a deep-seated emotion (Maia et al., 2019), towards places. This love can 198 exist in places that have not even been seen by the visitors (Swanson et al., 2017); nevertheless, every individual's experiences do not generate love (Ahuvia, 2005). Three different sorts of love exist between people and places. (1) philia, (2) storage, (3) eros. Philia describes the type of love that has similarities with friendship, while storage as a kind of love that is associated with affection and eros is a passionate and romantic love (Aro et al., 2018). Swanson et al. (2017) suggest that different destinations attract different types of love, and therefore, destination marketing should understand the kind of love that current loyal visitors feel to make the place adorable for them and other visitors, and also to maintain a long-term relationship with visitors. In conclusion, based on the arguments provided, it could be deduced that the two concepts of brand love and destination concept could bring together to create a new concept of destination brand love, which is more sophisticated, attractive, comprehensive and possibly useful in the tourism context.

\section{Methodology}

\subsection{Data collection}

212 The data for this study was collected from TripAdvisor, an online platform

213 (https://www.tripadvisor.com) which is one of the most used platforms by visitors to share their 214 opinions and experiences. All the reviews written by customers could be categorized as 215 positive, negative or neutral. Positive reviews are defined as those reviews that contain words 216 that could be used to investigate the aspects of the places which lead to a positive experience 217 and which result in customer satisfaction whereas negative reviews are those that could be used 218 to investigate the aspects that lead to a negative experience and result in dissatisfaction. Neutral 219 reviews are those that only contain information about the place such as location, services or 220 even weather. The data collection was carried out using the available reviews from October 2212008 until July 2019. The total number of reviews were used in this study were around 14604 222 from 95 places including landmarks and sites section of the website. The reason behind 
223 choosing landmarks and sites is rooted in the fact that Iran as a historical country possess

224 different historical destinations, which are the main visiting attractions for both domestic and 225 foreign tourists. For example Persepolis as a historical place, which was the ceremonial capital 226 for the Achaemenid Empire (ca. 550-330 BC) is among the most famous and visited site 227 among both domestic and foreign tourists. This place has been declared as a world heritage site 228 by the UNESCO in 1979.

229 In order to standardize the data, places with less than 30 reviews were excluded from the 230 dataset. A large portion of the reviews were from ancient sites like Persepolis or Bistoon which 231 are considered as the country's main attractions for both foreign and domestic visitors. 232 Furthermore, there is a large number of reviews that can be found online for other tourist 233 attractions like religious sites including mosques, cathedrals, or traditional shopping locations 234 like bazaars.

\subsection{Research approach}

236 New methods of research, such as text mining, in comparison to traditional ones, like surveys 237 or interviews, enable researchers to study an enormous amount of textual data more easily. 238 Considering the amount of data, we chose text mining to overcome possible information 239 overload (Xu \& Li, 2016) in order to identify the relevant topics among visitors.

240 In this study, the proposed method consisted of two steps which were the extraction of topics 241 and content analysis. As the first stage of the first step, we used LDA, a popular technique of 242 the machine learning methods in order to identify the discussed topics in reviews (Guo et al., 243 2017; Tirunillai \& Tellis, 2014) which is widely used in order to identify relevant topics in 244 large-scale texts by different scholars (Blei et al., 2001) EDA is an algorithm in which each 245 review is considered as a combination of different topies in which words represent a specific "meaning" (Blei et al., 2003; Poria et al., 2016). The number of chosen topics must be selected manually in the LDA algorithm. To obtain the best results, various models with different numbers of topies were created, and the optimum number of the topies was identified by choosing the model exhibiting the lowest score on perplexity.

250 LDA assumes that the document is comprised of number of different topics, which each word 251 in the document is in relation with one of the topics. In this method the output extracted from 252 the LDA algorithm include number of keywords that according to LDA algorithm are related 253 with each other. In order to obtain the best results, there is a need for different models to be 254 generated with different number of topics. The outputs of the model which are the relevant 
keywords must be investigated manually in order to remove the irrelevant keywords that have been wrongly selected by the model (Bi et al., 2019). The most efficient tested model has to be selected by perplexity number which is an indicator for the efficiency of the model. This means that the model with the less perplexity number represents the most efficient one. In the next step, a name is given to each topic based on the remaining keywords For example, mosque, square, palace and architecture have been generated under a topic, which all these share a common characteristic which based on the structure of the building, hence the topic was named as architecture.

269 Topic keywords were used as filters to specify the sentences containing information about each discussed topic or aspect of the places and sentences that included each keyword were categorized as the container of customer sentiments about each topic.

272 In the second stage of the extraction step, reviews of each topic are categorized based on their 273 sentiments. Multiple methods have been used in the context of tourism to classify online 274 reviews based on the visitors' sentiments. The most preferred methods among scholars in 275 tourism studies are Naïve Bayes and Support Vector Machines (SVM). These methods work 276 best when categorizing the input text into two classes, positive and negative, in the case of sentiment analysis. SVM is an algorithm that requires training by the labeled data to find the optimal hyperplane for dividing a set of data into different groups while Naïve Bayes considers each feature independently and uses Bayes's theorem to categorize the data (Alaei et al., 2019)

280 Since more than two classes have been considered for sentiment analysis, in this study, we have used OVO-SVM as the most accurate algorithm for multi-class sentiment classification (Bi et al., 2019).

283 Generally speaking, reviews can be classified into the three classes of positive, neutral or negative which are needed to train the machine in each set of labeled data. These sets of training data were created by reading a proportion of reviews and labeling them manually before training the machine. In the next stage, both the training set and unlabeled data had to be 
converted into features. Therefore, a Bag-of-word (BOW) model was adapted to construct the features. Following the feature generation step, along with the study of (Alaei et al., 2019), to optimize the outcome of the machine, the most appropriate features were selected using

290 the information gain (IG) algorithm. These features were used to train the (OVO-SVM)

291 classifier.

292 In the final step, to investigate the brand love constructs in the reviews, we used content 293 analysis. It is defined as systematic and detailed analysis of different types of data to identify 294 latent meanings, themes, and assumptions (Berg \& Latin, 2011, ; Leedy \& Ormrod, 2005)

295 . Since love is a positive emotion, in the content analysis of this study only positive reviews of each topic were used. Brand love in online reviews can be investigated through the analysis of

297 the keywords frequency and phrases that are used by the visitors of the place. For example, if 298 a visitor uses a phrase like "this place makes me relaxed", it can be concluded that the "positive 299 emotion connection", which is one of the constructs in the proposed model by (Batra et al., 300 2012), is available in the review. The process of the used methodology for the study is shown 301 in figure (1).

\section{"Insert Figure 1 here"}

\section{4. Findings}

304 In this section, a case study of the proposed method is given to demonstrate the usage of the 305 method. In this section, first the specifications of the data set are given and then the procedure 306 is explained.

\subsection{Extracting discussed topics among visitors}

308 Along with the procedure explained in section 3, discussed topics among visitors are extracted 309 in this step. Four topics are discovered to be discussed among visitors. Discussed topics are 310 architecture, tradition, historical sites, and shrine places, which are mainly considered as the 311 tourists' attractions in countries, such as Iran. This could be due to the fact that majority of 312 tourist with the taste of adventure or archeological background would consider visit historical 313 countries to experience a different culture and tradition. 
316 . After the manual analysis of the generated keywords for each topic, noisy words are removed,

317 and the remaining keywords are used to filter the sentences of the reviews by the topics. The 318 summary of the procedure is shown in Table 1. In Table 1, "Topic keywords" are the words 319 extracted from the topic modeling process. "The number of words" is the number of the 320 remaining words used to obtain reviews of each topic, and "the number of reviews" is the 321 number of reviews in which each topic is discussed.

\section{"Insert Table 1 here"}

\subsection{Extracting sentiments associated with each attribute}

324

325

OVO-SVM is used to extract sentiments from reviews associated with each topic. Reviews are classified into three classes: Class 1: Positive, Class 0: Neutral, Class -1: Negative. The neutral category consists of reviews that only have information about the place. For example:

"Located a little less than an hour..., this world-famous archaeological site was.... Like most large structures built by the Persian Empire, it was built...."

It only contains information about the location and history of the place and does not seem to contain any positive or negative sentiments. While:

"Our driver gave us a bit of historical background. The place was really interesting.' 'We have visited the Towers of Silence ... it was the best what we have seen this day...!"

represents a positive sentiment of a visitor and:

"please don't waste your time by going there .we saw different billboards for Saryazd and fortress and buggy road and safaris but when we drove 30 min and saw there found all of them were bubble and no more we came back to see Amir Chaghmagh sq. $"$

represents a negative sentiment about the destination. In order to train the classifier, 750 reviews were manually labelled. A summary of the results of the sentiment analysis is shown in Table 2.

"Insert Table 2 here" 


\subsection{Content analysis}

349 The constructs of brand love proposed by (Batra et al., 2012) were used as a reference to start the manual coding. To begin this stage, first, frequent phrases in positive reviews of each topic were extracted and organized in a spreadsheet. In the next step these extracted phrases where categorized under the constructs of the adopted model. For example, the word fantastic which is used by a person when a positive emotion towards a place emerges was categorized under positive emotional connection construct. In the method proposed by (Batra et al., 2012), 14 underlying elements of brand love were extracted by factor analysis. These first-order constructs were categorized in a higher-order hierarchical structure. The definition for each construct is explained in Table 3.

Since the proposed model by (Batra et al., 2012) was developed for consumer goods, to apply the model for the tourism industry, some of the construct's definitions were modified by the research team. For example, the antecedent of brand love is defined as the functional quality of the brand, which does not seem to be applicable in the tourism industry since the place has no function for the visitor. Instead of this concept, the perceived quality of the place is defined by this construct. The quality of the place can be investigated by counting keywords like amazing, fantastic, etc. Phrases associated with brand love for each topic are shown in figure 2.

\section{"Insert Figure 2 here"}

For example, in the review below:

"Love the place. The house is amazing....This house has beautiful gardens which were especially good ... Everything has been restored to perfection. Definitely worth a visit"

Phrases that can be categorized as constructs of brand love are shown in Table 4.

\section{"Insert Table 4 here"}

Table 5 shows the accumulated frequency of keywords and phrases of each topic. Since the number of associated reviews with each topic differentiates it from other topics, the accumulated frequencies are normalized by the number of available phrases in all topic reviews. The normalized accumulated frequencies are shown in Table 6. 
383 Since the primary purpose of this study is to investigate the destination brand love and different aspects of the place brands, each topic is explained separately.

\section{Discussion}

386

In this study, four different topics have been generated by analyzing the online reviews posted on TripAdvisor about the most visited landmarks and sites in Iran. Analysis of the reviews in this study is based on the brand love constructs which were borrowed from (Batra et al., 2012), which are: High Quality; Self-Brand Integration; Passion-Driven Behaviors and Positive Emotional Connection; Long-Term Relationship; Anticipated Separation Distress; Attitude Valence, and Attitude Strength. In addition, the consequences of the antecedents mentioned above are loyalty, WOM and resistance that have also been shown in Table 6 .

The first topic extracted from the reviews, with around 5292 comments was about the design and the structure of the places which so the topic was designated as "architecture". On the measuring of brand love, the antecedent used for this topic, with around 1500 comments, was Perceived Quality of the places, which plays the main role in generating a positive feeling for visitors. In addition, according to (Hanna \& Rowley, 2011a) the primary aim of destination branding is to create a positive connection and a good image for visitors which could be achieved through Perceived Quality. As a result, according to (Suzanne et al., 2020) an appropriate destination image could influence the visitors' decision about their travel, purchasing and investing. On the other hand, Attitude Strength, which has been defined as thinking and talking about the brand frequently, is the most commented core-element of destination brand love. This could potentially mean customers have created an emotional attachment with the place which could lead to their revisit due to positive past memorable experience that may cause the tourists to follow a repetitive decision pattern for their future travels (Manthiou et al., 2018). In other words, creating an online brand community, where tourists could share their information and opinion about the destination could be a solution for maintaining and reinforcing the relationship with the former visitors. This not only could encourage the former visitors to pay a revisit but it could also attract more tourists to the destination (Arnaldo et al., 2019). 
411 In addition, both Perceived Quality and Attitude Strength have positive impacts on both WOM 412 and E-WOM (Karjaluoto et al., 2016) that could lead to possible reduction in marketing 413 expenses and eventually help the brand to distinguish itself from others (Qumsieh \& Tajeddini, 414 2016).

415 Historical sites are the second most discussed topic among visitors. It was discussed in around 4165041 review comments posted online. Similar to architecture, Perceived Quality received a 417 high number of comments, which could indicate that there is a positive feeling and attachment 418 between visitors and places (Hanna \& Rowley, 2011b) In addition, the most commented on 419 core-element in this topic is Positive Emotional Attachment. Given that Positive Emotional 420 Attachment is much deeper than a simple positive feeling, (Drennan et al., 2015) argue that 421 those brands that are capable of creating a positive emotional attachment are more able to 422 attract deeper love from the visitors, which could result in creating a stronger competitive 423 advantage for their brand as compared to others that do not. In other words, according to (Batra et al., 2012) those brands that have a root in the hearts of their producers more easily find a place in their customers' hearts as well. On the other hand, the second most commented on core-element of brand love that is discussed in the topic of historical sites is Anticipated Separation Distress. From reading the comments posted online it could be induced that the reason for the large number of comments on this core-element has a root in the fact that there is general distress and anxiety among visitors on the potential disappearance of the historical sites in the near future as a result of natural (e.g. earthquake) or manmade damage (e.g. new constructions). Another reason for the high number of comments on this core-element could possibly be because visiting historical sites, such as Persepolis with its magnificent architecture and rich history, creates an emotional attachment among visitors and, therefore, the possibility of damage to such places could cause anxiety and worry among visitors who love or have emotional attachment toward them. Moreover, it worth mentioning that the number of comments on the core-element of attitude strength on the topic of history is far lower than what have been found and mentioned on the topic of architecture. In the first view the results seems to be surprising, since majority of tourism scholars strive to highlight the importance of the historical sites in Iran, as more attractive tourism sectors, rather than other tourism attractions.

440 However, having said that, this could be due to fact that the way this study categorized the core-elements where, for example under the architecture topic, there are places, such as mosque and palace, which in terms of number they are far greater than historical sites, which includes ancient and unique places like Persepolis. 
The third most commonly discussed topic among visitors was tradition, which is related to visitors' feelings toward the peoples' values, beliefs and traditions of the host country. In this topic, the perceived quality antecedent has been emphasized less as compared to architecture and historical sites. On the other hand, the positive emotional core-element has been commented on more compared to the other two topics. The reason for there being a high number of comments on this core-element could be related to the rich cultural and historical background of Iran, which is amazingly diverse in terms of its religions, languages, dialects and rituals (Khodadadi \& Donnell, 2017). Therefore, as (Batra et al., 2012) argue, positive emotional attachment can create an intuitive feeling of rightness, so brands must act in a way to generate more positive emotion among visitors by highlighting their authenticity which has its root in their history. Furthermore, positive comments by the travelers, which indicate emotional attachment towards a place, could potentially create an opportunity for the brands not only to generate excitement among future visitors but also create a sense of closeness and bonding toward the brand among people who have yet to visit (Swanson et al., 2017). On the other hand, the analysis of the visitors' comments illustrate that the core-element of Self-Brand Integration only exists with the topic of tradition, which could signal the importance of both extrinsic (e.g., transportation) and intrinsic (e.g., happiness) reward factors among visitors. For brands to generate brand love among visitors, they need to create an experience that is not only based on relaxation and entertainment but also more importantly has a root in the existential meaning of life that creates a deep connection and emotional attachment between visitors and the place's cultural and historical values (Batra et al., 2012).

465 The final topic generated from the visitors' comments was shrine places, which is about holy 466 and spiritual places. The data shows, as compared to other topics, this topic has received far fewer comments in all antecedent and core-elements of brand love. This could be as a result of religious differences between locals and visitors, which possibly make the holy and spiritual places become less attractive for them as compared to other landmarks and sites. As (Khaksari et al., 2014) argues, tourism development strategies in Muslim countries such as Iran will not necessarily lead to attracting more travelers, so long as the authorities are unwilling to alter or relax some customary rules and regulations. However, as can be seen in Table 6, although, shrine places has received positive comments from visitors, the number of comments specifically for WOM and E-WOM were far fewer than for the other topics. This could be an fruitful basis, for both scholars and practitioners, for future studies of religious and spiritual tourism. 


\subsection{Overall destination brand love}

478 As a result of the content analysis, it could be deduced that the intensity and the number of the

479 comments posted online on each antecedent and core-element of brand love for each topic, is 480 very much dependent on visitors' emotional feelings and attachment to the place, which may 481 be different case by case. Furthermore, our results show that architecture as a topic plays the 482 most important role in creating brand love among visitors with historical places in second place.

483 In terms of the antecedent and core-elements of brand love, Perceived Quality received the 484 greatest number of comments with Positive Emotional Connection in second place. This could 485 indicate that the importance of both Perceived Quality and Positive Emotion in creating 486 Emotional Attachment, which eventually could result in brand love. In a general overview, Out 487 of seven core-elements introduced by (Batra et al., 2012) to measure brand love in general in 488 this study, only three of them have been mentioned by the visitors in great detail in the context 489 of landmarks and sites and the other four either have not been mentioned at all or have been 490 mentioned infrequently. The reason behind not receiving any comments on these two core491 elements; passion-driven behaviors and long-term relationship could be due to the fact that 492 current political situation in Iran that has made the country economically and politically 493 isolated could be counted as the substantial obstacle for the foreign tourists not to maintain a 494 long relationship with the tourist destinations in Iran.

495 Furthermore, another conclusion that can be drawn from the analysis is that positive WOM and 496 E-WOM can be achieved when visitors' emotional feeling is at a high level, which could 497 potentially create brand love. In our study both architecture and historical sites as two main 498 topics of brand love generated a large amount of WOM and E-WOM, which could indicate 499 visitors felt a strong connection and emotional attachment with the architecture, design and 500 atmosphere of the places.

\section{Theoretical and practical implications}

502 Customer online reviews have recently gained attention among scholars and practitioners in 503 the tourism and hospitality industry ( $\mathrm{Xu} \& \mathrm{Li}, 2016)$. This study used a mixed method of 504 machine learning and content analysis to investigate the process of creating destination brand 505 love in the tourism context by using the (Batra et al., 2012) brand love model. The current 506 research is the first of its kind that uses the (Batra et al., 2012) model for measuring brand love 507 and expanding it to the context of tourism to measure destination brand love specifically 508 through comments posted online. 
510 Our study offers several contributions including theoretical, practical and methodological ones.

511 The theoretical contribution of this study lies in the fact that by reviewing online comments we

512 have managed to generate topics that are influential in creating destination brand love in the

513 tourism context of historical and ancient places, such as Iran. To do so, this study has chosen a

514 conceptual model proposed by (Batra et al., 2012) which consists of service quality as an

515 antecedent and seven core-elements for identifying the precise impact of each construct in this

516 model on brand love creation. Adopting the mentioned model into other consumption

517 categories such as destination could provide knowledge for academics to understand what a

518 destination can offer to satisfy its visitors and increase the chances of a revisit. In addition,

519 obtaining information about the visitors through online reviews, assists academics and

520 researchers to recognize the influence of each destination attribute on the tourists' decision for

521 selecting or not selecting a destination. This could indicate that destinations, in order to create

522 competitive advantage and distinguish themselves, require a set of benefits for the visitors that

523 is not only based on entertainment and relaxation, but is also able to create positive feelings

524 and emotional attachment during the experience of visiting the place (Batra et al., 2012;

525 Swanson et al., 2017). These results indicate that destination brand love, as a specific type of

526 brand love, requires its own construct and measurement which might be similar in some

527 respects, but certainly different in many other respects, from measuring brand love in general.

528 Therefore, this study has shed a light on the importance of conducting future studies in this

529 specific field of the tourism industry.

530 Additionally, in terms of method this study also contributes to the existing literature by 531 proposing a mixed method comprising machine learning and content analysis to investigate the 532 concept of destination brand love by analysing visitors' online reviews. In fact, using online 533 reviews as a source of data to conduct research has a number of advantages compared to 534 traditional data sources. First, traditional data gathering methods generally produce a very 535 limited amount of information which can also result in biased analysis and incorrectly drawn 536 conclusions (Guo et al., 2017). Furthermore, traditional data collection methods can generate 537 results that make a very limited contribution that prevent researchers from having a deeper 538 understanding of the concept (Barsky, 1992; Fornell, 1992). Second, unlike traditional data 539 sources, online reviews can be gathered in large quantities because online reviews are 540 generated daily by passionate and consciousness customers, who love to share their experiences 541 with others (Guo et al., 2017), and it is independent from the time of data gathering. 
543 Besides the theoretical implications, this study makes several practical contributions. First, by

544 considering the crucial outcomes of brand love (e.g., positive WOM and resistance to negative 545 information), it is essential for the destination decision-makers to monitor brand love as a 546 performance indicator for their brands. While the traditional methods have several limitations, 547 the proposed method enables decision-makers to measure destination brand love in less time 548 and with less effort. Furthermore, by adopting this method marketers and managers can identify 549 those factors that are more influential in creating brand love among visitors and, as a result, 550 they will be able to allocate resources more efficiently helping them to reduce the cost of 551 marketing in the long run.

552 On the other hand, there is increasing competition among destinations to attract more tourists 553 (Medway et al., 2010), and therefore, it is very challenging for any destination to maintain their 554 unique brand identity (Jamrozy \& Walsh, 2008). Hence, selecting appropriate positioning plays 555 a significant role in attracting visitors to destination brands. Therefore, the proposed model 556 could potentially help managers to select the most appropriate attribute of the place for 557 positioning destination brands better by investigating more efficiently those attributes that help 558 to create emotional attachment and love between the visitors and the place. Thus, the practical 559 contribution of this study lies in the fact that this knowledge enables tourist managers to 560 recognize what attributes of the places they need to emphasize in the destination marketing to 561 distinguish their brands from others and also how they can tailor the destination to fulfill the 562 customers' need (Qumsieh \& Tajeddini, 2016).

\subsection{Future studies}

564 Due to the limitations of this study, which are related to the measurement resistance of negative on line-reviews and the use of an optimized algorithm, it is proposed that future studies be based on cross-culture analysis with more data. Similarly, by the virtue of technology advancement, future studies in this area and in the context of tourism will require more sophisticated and optimized algorithms of machine learning that enable researchers not only to collect a larger data set, but also to analyze collected data more efficiently and effectively. Another limitation of this study is data collection, which is based on secondary data and in future study's authors or researchers could also add primary data for better understanding the concept. In addition, it is suggested that in future studies researcher should consider collecting 
these visitors. Furthermore, this study has a limitation in looking only at historical landmarks, thus future studies could focus on other consumption categories, such as hotels.

\section{References}

Ahuvia, A. (2005). Beyond the Extended Self: Loved Objects and Consumers' Identity Narratives. Journal of Consumer Research, 32, 171-184. https://doi.org/10.1086/429607

Ahuvia, A. C. (1992). For the love of money $\square$ : Materialism and product love. January 1992.

Alaei, A. R., Becken, S., \& Stantic, B. (2019). Sentiment Analysis in Tourism: Capitalizing on Big Data. Journal of Travel Research, 58(2), 175-191. https://doi.org/10.1177/0047287517747753

Albert, N., Merunka, D., \& Valette-florence, P. (2008). When consumers love their brands $\square$ : Exploring the concept and its dimensions. 61, 1062-1075. https://doi.org/10.1016/j.jbusres.2007.09.014

Arnaldo, C., Cristela, B., \& Filipa, P. (2019). Brand communities' relational outcomes, through brand love. Journal of Product \& Brand Management, 28(2), 154-165. https://doi.org/10.1108/JPBM-09-2017-1593

Aro, K., Suomi, K., \& Saraniemi, S. (2018). Antecedents and consequences of destination brand love - A case study from Finnish Lapland. Tourism Management, 67, 71-81. https://doi.org/10.1016/j.tourman.2018.01.003

Ashworth, G., \& Kavaratzis, M. (2007). Beyond the logo $\square$ : Brand. 16, 520-531. https://doi.org/10.1057/palgrave.bm.2550133

Bairrada, C. M. (2018). The impact of brand personality on consumer behavior $\square$ : the role of brand love. https://doi.org/10.1108/JFMM-07-2018-0091

Barsky, J. D. (1992). Customer Satisfaction in the Hotel Industry: Meaning and Measurement. Hospitality Research Journal, 16(1), 51-73. https://doi.org/10.1177/109634809201600105

Batra, R., Ahuvia, A., Bagozzi, R. P., \& Love, B. (2012). Brand Love. 76(March), 1-16.

Berg, K. E., \& Latin, R. W. (2011). Essentials of research methods in health, physical 
Bi, J., Liu, Y., Fan, Z., \& Zhang, J. (2019). Wisdom of crowds $\square$ : Conducting importance-

603

604

605

606

607

608

609

610

611

612

613

614

615

616

617

618

619

620

621

622

623

624

625

626

627

628 performance analysis ( IPA ) through online reviews. Tourism Management, 70(July 2018), 460-478. https://doi.org/10.1016/j.tourman.2018.09.010

Bi, J. W., Liu, Y., Fan, Z. P., \& Zhang, J. (2019). Wisdom of crowds: Conducting importanceperformance analysis (IPA) through online reviews. Tourism Management, 70(September 2018), 460-478. https://doi.org/10.1016/j.tourman.2018.09.010

Blain, C., Levy, S., \& Ritchie, J. (2005). Destination Branding: Insights and Practices from Destination Management Organizations. Journal of Travel Research, 43, 328-338. https://doi.org/10.1177/0047287505274646

Blei, D. M., Ng, A. Y., \& Jordan, M. I. (2003). Latent Dirichlet Allocation. 3, 993-1022.

Blei, D., Ng, A., \& Jordan, M. (2001). Latent Dirichlet Allocation. The Journal of Machine Learning Research, 3, 601-608.

Carroll, B. A., \& Ahuvia, A. C. (2006). Some antecedents and outcomes of brand love. 79-89. https://doi.org/10.1007/s11002-006-4219-2

Castañeda-García, J. A., Frías-Jamilena, D. M., Del Barrio-García, S., \& Rodríguez-Molina, M. A. (2019). The Effect of Message Consistency and Destination-Positioning Brand Strategy Type on Consumer-Based Destination Brand Equity. Journal of Travel Research, 0047287519881506. https://doi.org/10.1177/0047287519881506

Cheng, C.-K., \& Kuo, H.-Y. (2015). Bonding to a new place never visited: Exploring the relationship between landscape elements and place bonding. Tourism Management, 46(C), 546-560. https://econpapers.repec.org/RePEc:eee:touman:v:46:y:2015:i:c:p:546560

Drennan, J., Bianchi, C., Cacho-elizondo, S., Louriero, S., Guibert, N., \& Proud, W. (2015). International Journal of Hospitality Management Examining the role of wine brand love on brand loyalty $\square$ : A multi-country comparison $\square$. International Journal of Hospitality Management, 49, 47-55. https://doi.org/10.1016/j.ijhm.2015.04.012

Fornell, C. (1992). A National Customer Satisfaction Barometer: The Swedish Experience. 
630 Fournier, S. (1998). Consumers and Their Brands: Developing Relationship Theory in 631 Consumer Research. Journal of Consumer Research, 24, 343-373.

Govers, R., \& Go, F. M. (2009). Place Branding $\square$ : Glocal, Virtual and Physical Identities, 634 Constructed , Imagined and Experienced. July, 2009-2011. https://doi.org/10.1016/j.tourman.2010.06.002

636

637

638

639

640

641

642

643

644

645

646

647

648

649

650

651

652

653

654

655

656 https://doi.org/10.1086/209515

Guo, Y., Barnes, S. J., \& Jia, Q. (2017). Mining meaning from online ratings and reviews $\square$ : Tourist satisfaction analysis using latent dirichlet allocation. Tourism Management, 59, 467-483. https://doi.org/10.1016/j.tourman.2016.09.009

Hammitt, W. E., Kyle, G. T., \& Oh, C.-O. (2009). Comparison of Place Bonding Models in Recreation Resource Management. Journal of Leisure Research, 41(1), 57-72. https://doi.org/10.1080/00222216.2009.11950159

Hanna, S., \& Rowley, J. (2011a). Towards a strategic place brand- management model Towards a strategic place brand-management model. July 2015. https://doi.org/10.1080/02672571003683797

Hanna, S., \& Rowley, J. (2011b). Towards a Strategic Place Brand-management Model. Journal of Marketing Management, 27, 458-476. https://doi.org/10.1080/02672571003683797

Hou, J., Lin, C., \& Morais, D. B. (2005). Antecedents of Attachment to a Cultural Tourism Destination $\square$ : The Case of Hakka and Non-Hakka. https://doi.org/10.1177/0047287505278988

Huang, T. L. (2019). Psychological mechanisms of brand love and information technology identity in virtual retail environments. Journal of Retailing and Consumer Services, 47(July 2018), 251-264. https://doi.org/10.1016/j.jretconser.2018.11.016

Jamrozy, U., \& Walsh, J. A. (2008). Destination and place branding: A Lost Sense of Place? 131-141.

Karjaluoto, H., Munnukka, J., \& Kiuru, K. (2016). Brand love and positive word of mouth: the 
657

658

659

660

661

662

663

664

665

666

667

668

669

670

671

672

673

674

675

676

677

678

679

680

681

682

683

684

moderating effects of experience and price. Journal of Product \& Brand Management, 25, 527-537. https://doi.org/10.1108/JPBM-03-2015-0834

Kathryn, S. (2017). Destination brand love: managerial implications and applications to tourism businesses. Journal of Place Management and Development, 10(1), 88-97. https://doi.org/10.1108/JPMD-11-2016-0073

Khaksari, A. L. I., Lee, T. J., \& Lee, C. (2014). Religious Perceptions and Hegemony on Tourism Development $\square$ : the Case of the Islamic Republic of Iran. 103, 97-103. https://doi.org/10.1002/jt

Khodadadi, M., \& Donnell, H. O. (2017). Relocating Persia / Iran in the contemporary British tourist imaginary Relocating Persia / Iran in the contemporary British tourist. Leisure Studies, 4367(August), 0. https://doi.org/10.1080/02614367.2017.1353126

Maia, B. C., Arnaldo, C., \& Viktoriya, L. (2019). The impact of brand personality on consumer behavior: the role of brand love. Journal of Fashion Marketing and Management: An International Journal, 23(1), 30-47. https://doi.org/10.1108/JFMM-07-2018-0091

Malär, L., Krohmer, H., Hoyer, W. D., \& Nyffenegger, B. (2011). Emotional Brand Attachment and Brand Personality $\square$ : The Relative Importance of the Actual and the Ideal Self. 75(July), 35-52.

Manthiou, A., Kang, J., Sean, S., \& Xiao, X. (2018). International Journal of Hospitality Management The impact of brand authenticity on building brand love $\square$ : An investigation of impression in memory and lifestyle-congruence. International Journal of Hospitality Management, 75(March), 38-47. https://doi.org/10.1016/j.ijhm.2018.03.005

Medway, D., Warnaby, G., \& Dharni, S. (2010). Demarketing places: Rationales and strategies. Journal of Marketing Management, 27, 124-142. https://doi.org/10.1080/02672571003719096

Poria, S., Cambria, E., \& Gelbukh, A. (2016). Knowle dge-Base d Systems Aspect extraction for opinion mining with a deep convolutional neural network. 108, 42-49. https://doi.org/10.1016/j.knosys.2016.06.009

Pournarakis, D. E., Sotiropoulos, D. N., \& Giaglis, G. M. (2017). A computational model for 
685

686

687

688

689

690

691

692

693

694

695

696

697

698

699

700

701

702

703

704

705

706

707

708

709

710

711

Prayag, G., \& Ryan, C. (2012). Antecedents of Tourists’ Loyalty to Mauritius: The Role and mining consumer perceptions in social media. Decision Support Systems, 93, 98-110. https://doi.org/https://doi.org/10.1016/j.dss.2016.09.018 Influence of Destination Image, Place Attachment, Personal Involvement, and Satisfaction. Journal of Travel Research, 51(3), 342-356. https://doi.org/10.1177/0047287511410321

Qumsieh, G., \& Tajeddini, K. (2016). Journal of Hospitality and Tourism Management Tourism in Switzerland $\square$ : How perceptions of place attributes for short and long holiday can in $\mathrm{fl}$ uence destination choice. Journal of Hospitality and Tourism Management, 26, 18-26. https://doi.org/10.1016/j.jhtm.2015.09.003

Reimann, M., Castaño, R., Zaichkowsky, J., \& Bechara, A. (2012). How we relate to brands $\square$ : Psychological and neurophysiological insights into consumer - brand relationships. $\begin{array}{llll}\text { Journal of } \quad \text { Consumer } & \text { Psychology, }\end{array}$ https://doi.org/10.1016/j.jcps.2011.11.003

Suzanne, A., Cristina, B., \& Joaquim, A. (2020). Exploring the antecedents and outcomes of destination brand love. In Journal of Product \& Brand Management: Vol. ahead-of-print (Issue ahead-of-print). https://doi.org/10.1108/JPBM-08-2019-2487

Tirunillai, S., \& Tellis, G. J. (2014). Mining Marketing Meaning from Online Chatter: Strategic Brand Analysis of Big Data Using Latent Dirichlet Allocation. Journal of Marketing Research, 51(4), 463-479. https://doi.org/10.1509/jmr.12.0106

Tsai, S. (2012). Place Attachment and Tourism Marketing: Investigating International Tourists in Singapore. International Journal of Tourism Research, 14(2), 139-152. https://doi.org/10.1002/jtr.842

Xu, X., \& Li, Y. (2016). International Journal of Hospitality Management The antecedents of customer satisfaction and dissatisfaction toward various types of hotels $\square$ : A text mining approach. International Journal of Hospitality Management, 55, 57-69. https://doi.org/10.1016/j.ijhm.2016.03.003 
713 Sternberg, R. J. (1986). A triangular theory of love. Psychological Review, 93(2), 119-135

714 Rubin, Z. (1973). Liking and loving: An invitation to social psychology. Holt, Rinehart \& Winston.

715 Steele, F. 1981. The sense of place. Boston: CBI Publishing

716 Leedy, P.D. and Ormrod, J.E. (2005) Practical Research: Planning and Design. Prentice Hall, 717 Upper Saddle River, NJ. 
Figure 1 framework of the research

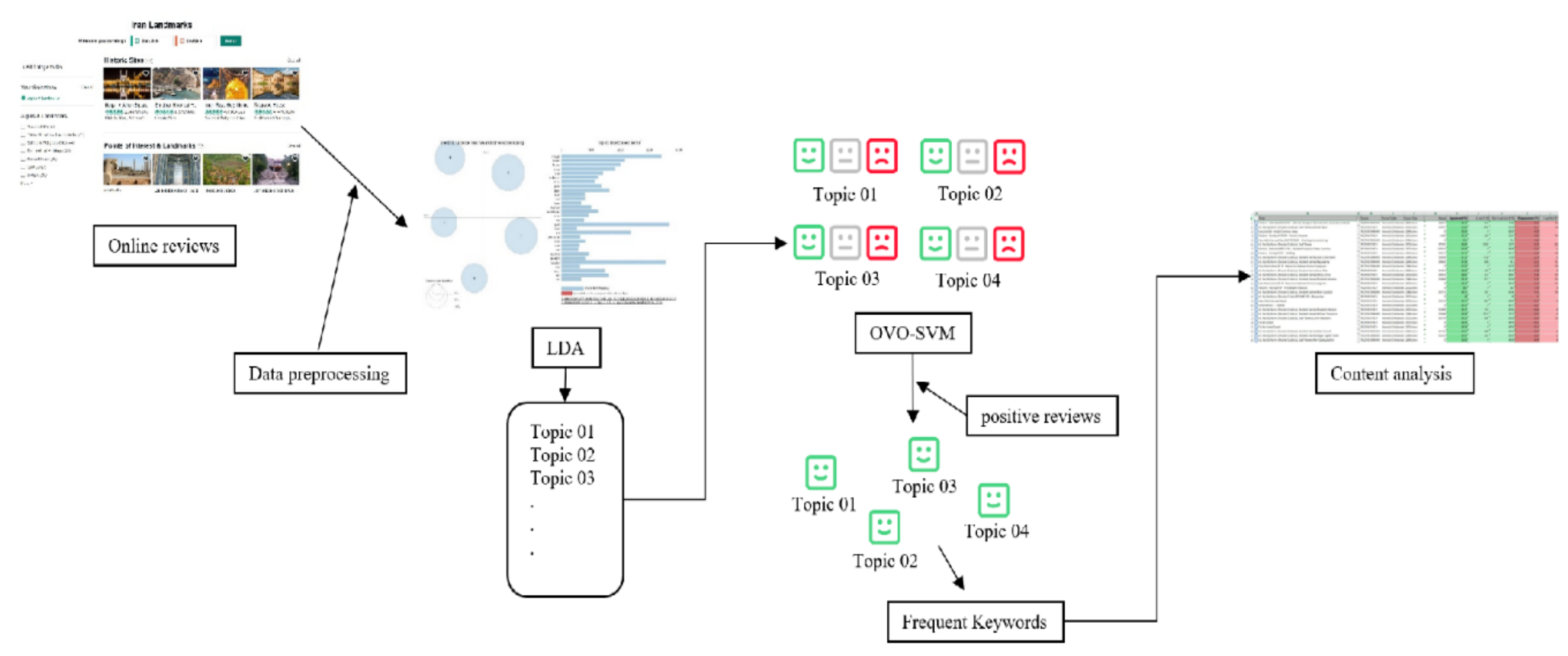


Figure 2 -Frequent keywords of topics

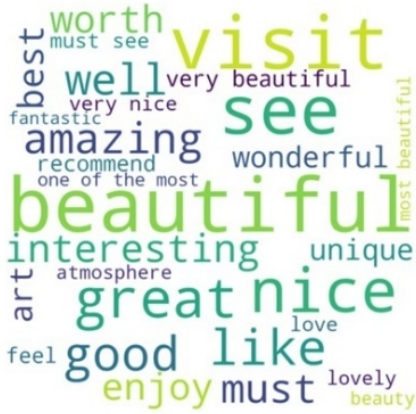

Architecture

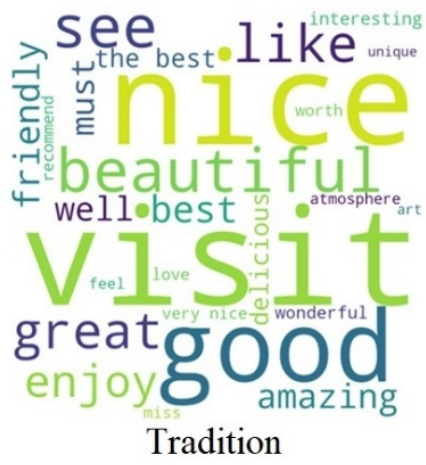

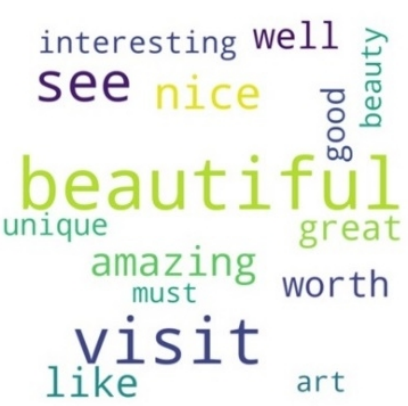

Shrine places

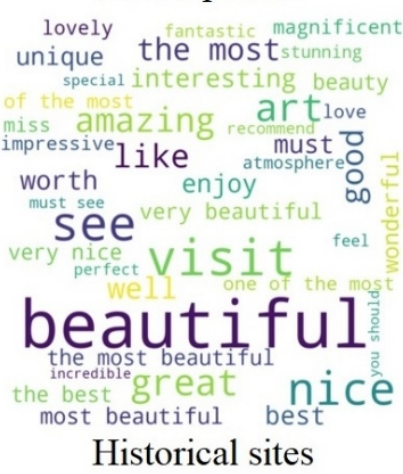


Table 1 - Topic keywords, number of words and number of reviews

\begin{tabular}{|c|c|c|c|}
\hline Topic & Topic keywords & $\begin{array}{r}\text { Number of } \\
\text { words }\end{array}$ & $\begin{array}{r}\text { Number of } \\
\text { reviews }\end{array}$ \\
\hline Architecture & mosque, square, palace, architecture, ... & 7 & 5292 \\
\hline Tradition & restaurant, people, food, traditional, ... & 9 & 4303 \\
\hline Historical sites & history, museum, ancient, castle, ... & 7 & 5041 \\
\hline Shrine places & shrine, holy, cathedral', 'mosque', ... & 6 & 2202 \\
\hline
\end{tabular}


Table 2 - The summary of the result of the sentiment analysis

\begin{tabular}{|l|l|l|l|}
\hline & Positive & Neutral & Negative \\
\hline Architecture & 4151 & 801 & 340 \\
\hline Historical sites & 3549 & 957 & 535 \\
\hline Tradition & 3006 & 699 & 598 \\
\hline Shrine places & 1557 & 425 & 220 \\
\hline
\end{tabular}


Table 3 -The definition for each construct of brand love

\begin{tabular}{|c|c|c|}
\hline \multicolumn{3}{|c|}{ Antecedent } \\
\hline High Quality & $\begin{array}{l}\text { The attitude about the functional quality } \\
\text { of the brand }\end{array}$ & (Batra et al., 2012) \\
\hline \multicolumn{3}{|c|}{ Core-elements } \\
\hline Self-Brand Integration & $\begin{array}{l}\text { Current self-identity: } \\
\text { The sharing attribute between self and } \\
\text { brand } \\
\text { Desired self-identity: } \\
\text { The sharing attribute between self and } \\
\text { brand } \\
\text { Life meaning and intrinsic rewards: } \\
\text { The brand is perceived as a means to } \\
\text { create meaning for life }\end{array}$ & (Batra et al., 2012) \\
\hline Passion-Driven Behaviors & $\begin{array}{l}\text { Willingness to invest resources: } \\
\text { Willing to spend resources including } \\
\text { money, time and energy for the brand } \\
\text { Passionate desire to use: } \\
\text { The feeling of passion and desire } \\
\text { toward the brand } \\
\text { Things that are done in the past } \\
\text { (involvement): } \\
\text { Past interactions with the brand }\end{array}$ & \\
\hline $\begin{array}{l}\text { Positive Emotional } \\
\text { Connection }\end{array}$ & $\begin{array}{l}\text { Intuitive fit: } \\
\text { The ability of the brand to meet the } \\
\text { psychological needs of the consumer } \\
\text { Emotional attachment: }\end{array}$ & \\
\hline
\end{tabular}




\begin{tabular}{|c|c|c|}
\hline & $\begin{array}{l}\text { The emotional bond between the } \\
\text { consumer and the brand } \\
\text { Positive affect: } \\
\text { the positive feelings (relaxing, excited, } \\
\text { etc.) towards the brand }\end{array}$ & \\
\hline Long-Term Relationship & $\begin{array}{l}\text { The feeling of commitment for a long } \\
\text { period for consumers }\end{array}$ & \\
\hline $\begin{array}{l}\text { Anticipated Separation } \\
\text { Distress }\end{array}$ & $\begin{array}{l}\text { The negative feelings that consumers } \\
\text { have during separation with brand }\end{array}$ & \\
\hline Attitude Valence & $\begin{array}{l}\text { The ability of the brand to meet the } \\
\text { expectations of the consumer }\end{array}$ & \\
\hline Attitude Strength & $\begin{array}{l}\text { Attitude strength 1: frequent } \\
\text { thoughts (part of self-brand } \\
\text { integration) } \\
\text { Consumers frequently talk and think } \\
\text { about the brand } \\
\text { Attitude strength 2: certainty and } \\
\text { confidence } \\
\text { The certainty and confidence of the } \\
\text { consumer in his/her attitude about the } \\
\text { brand }\end{array}$ & \\
\hline \multicolumn{3}{|c|}{ Consequences } \\
\hline Loyalty/WOM/Resistance & $\begin{array}{l}\text { Willingness to use again/ sharing } \\
\text { positive WOM/ resistance to negative } \\
\text { things about the brand }\end{array}$ & (Batra et al., 2012) \\
\hline
\end{tabular}


Table 4 - Sample of phrases

\begin{tabular}{|c|c|}
\hline High Quality & Amazing, lovely, beautiful, good, perfection \\
\hline \multicolumn{2}{|r|}{ Antecedent } \\
\hline Self-Brand Integration & - \\
\hline Passion-Driven Behaviors & - \\
\hline $\begin{array}{ll}\text { Positive } & \text { Emotional } \\
\text { Connection } & \end{array}$ & Love \\
\hline Long-Term Relationship & - \\
\hline $\begin{array}{l}\text { Anticipated Separation } \\
\text { Distress }\end{array}$ & - \\
\hline Attitude Valence & - \\
\hline Attitude Strength & Definitely worth a visit \\
\hline \multicolumn{2}{|r|}{ Consequence } \\
\hline Loyalty/WOM/Resistance & worth a visit \\
\hline
\end{tabular}


Table 5 -Accumulated frequency of keywords and phrases concerning each topic

\begin{tabular}{|c|c|c|c|c|}
\hline Topic & Architecture & $\begin{array}{l}\text { Historical } \\
\text { sites }\end{array}$ & Tradition & $\begin{array}{l}\text { Shrine } \\
\text { places }\end{array}$ \\
\hline Number of sentences & 5292 & 5041 & 4303 & 2202 \\
\hline \multicolumn{5}{|c|}{ Antecedents } \\
\hline $\begin{array}{c}\text { Perceived quality of the } \\
\text { place }\end{array}$ & 4571 & 2903 & 2182 & 1124 \\
\hline \multicolumn{5}{|c|}{ Core-elements } \\
\hline Self-Brand Integration & - & - & 130 & - \\
\hline Passion-Driven Behaviors & - & - & - & - \\
\hline $\begin{array}{l}\text { Positive Emotional } \\
\text { Connection }\end{array}$ & 582 & 644 & 724 & 111 \\
\hline Long-Term Relationship & - & - & - & - \\
\hline $\begin{array}{c}\text { Anticipated Separation } \\
\text { Distress }\end{array}$ & 101 & 102 & 73 & - \\
\hline Attitude Valence & 172 & 162 & 81 & 88 \\
\hline Attitude Strength & 1666 & 343 & 318 & - \\
\hline
\end{tabular}




\section{Consequences}

Table 6 -Normalized accumulated frequencies

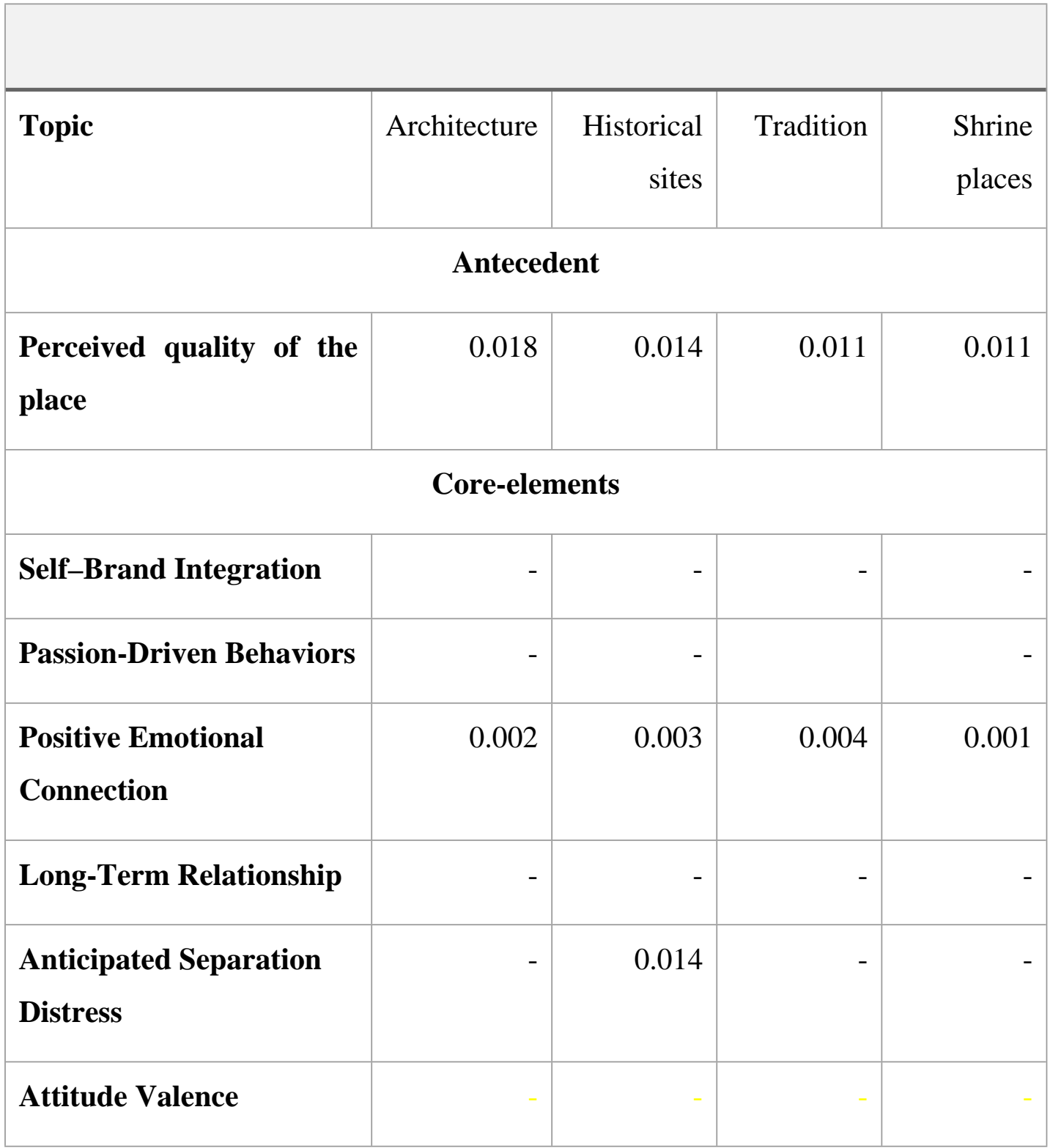




\begin{tabular}{|l|r|r|r|r|}
\hline Attitude Strength & 0.006 & 0.001 & 0.001 & - \\
\hline \multicolumn{5}{|c|}{ Consequence } \\
\hline Loyalty/WOM/Resistance & 0.006 & 0.006 & 0.005 & 0.005 \\
\hline
\end{tabular}

